DOI: https://doi.org/10.33739/2587-5434-2020-3-62-69

\title{
GEORGIAN LANGUAGE GRAMMAR TEACHING ASPECTS FOR NON-GEORGIAN SPEAKERS
}

\author{
Rusudan Saginadze \\ Doctor of Philology, Professor \\ Akaki Tseretely State University \\ (Kutaisi, Georgia) \\ e-mail: r_saginadze@yahoo.com
}

\begin{abstract}
Many questions arise in the process of language learning. It refers not only to the questions asked by language learners, but also to the problems faced by the specialists themselves. The issue of teaching grammar of the language, in particular, when, at what stage, how and in what doses, should grammatical materials be provided to the language learner is one of these problems. This problem is especially acute in case of teaching languages having complex grammatical systems. It can be said that Georgian language is considered to have rather complex structure, it is agglutinative language, which differs from other languages not only in phonemic structure, or specific sounds, but also in morphosyntactic level. As scholars point out, one of the main determinants of complexity and, at the same time, diversity is the polypersonalism of the Georgian verb. The abundance and functional diversity of prefixes must be added to this.

The aim of the article is to find ways to solve mentioned problems. The research is based on the methodology, methods of analysis and comparison existed in Georgian or foreign scientific literature. Taking into account the opinions of specialists and the teaching methods given in the textbooks, the paper analyzes the problems encountered in the process of teaching Georgian to non-Georgian speakers, in particular, outlines aspects of grammar teaching, draws appropriate conclusions. It is noted that when teaching Georgian to non-Georgian speakers, subjective and objective factors should be taken into account (category of language learner, motivation, structure of the language to be studied, specifics, form of teaching, when, at what stage, in what dose and means to provide grammatical material); In the initial stage of learning, the language learner should be provided with grammatical material not at once, but in doses necessary for communication, grammar charts, tables, exercises and not theoretical materials and rules, and in later stages the material may be increased according to language proficiency levels.
\end{abstract}

Keywords: Grammar, teaching, stages, learner, methods

\section{АСПЕКТЫ ПРЕПОДАВАНИЯ ГРАММАТИКИ ГРУЗИНСКОГО ЯЗЫКА ДЛЯ НЕГРУЗИНОГОВОРЯЩИХ}

\author{
Русудан Сагинадзе \\ Доктор филологии, профессор \\ Государственный университет имени Акакия Церетели \\ (Кутаиси, Грузия) \\ e-mail: r_saginadze@yahoo.com
}

Аннотация. В процессе изучения языка возникает множество вопросов. Речь идет не только о вопросах, задаваемых изучающими язык, но и о проблемах, с которыми сталкиваются сами 62 
специалисты. Одной из таких проблем является вопрос обучения грамматике языка, в частности, когда, на каком этапе, как и в каких дозах должен предоставляться грамматический материал изучающему язык. Особенно остро эта проблема стоит в случае преподавания языков со сложными грамматическими системами. Можно сказать, что грузинский язык считается достаточно сложным, это агглютинативный язык, который отличается от других языков не только фонемической структурой или специфическими звуками, но и морфосинтаксическим уровнем. Как отмечают ученые, одним из основных определяющих факторов сложности и, в то же время, разнообразия является полиперсонализм грузинского глагола. К этому следует добавить изобилие и функциональное разнообразие приставки.

Целью статьи является поиск путей решения указанных проблем. Исследование основано на методологии, методах анализа и сравнения, существовавших в грузинской или зарубежной научной литературе. Принимая во внимание мнения специалистов и методику преподавания, изложенную в учебниках, в статье анализируются проблемы, возникшие в процессе преподавания грузинского языка негрузиноязычным студентам, в частности, очерчиваются аспекты преподавания грамматики, делаются соответствующие выводы. Отмечается, что при обучении негрузиноязычным грузинскому языку необходимо учитывать субъективные и объективные факторы (категория изучающего язык, мотивация, структура изучаемого языка, специфика, форма обучения, когда, на каком этапе, в какой дозе и какими средствами обеспечить грамматический материал). На начальном этапе обучения изучающий язык должен быть обеспечен грамматическим материалом не сразу, а в дозах, необходимых для общения, грамматических таблицах, таблицах, упражнениях, а не теоретическими материалами и правилами, а на более поздних этапах материал может быть увеличен в зависимости от уровня владения языком.

Ключевые слова: грамматика, преподавание, этапы, учащийся, методы

\section{INTRODUCTION}

Many questions arise in the process of language learning. We mean not only the questions posed by language learners, but also the problems faced by the specialists themselves. The issue of teaching grammar, in particular, when, at what stage, by what means and in what doses, grammatical material is provided to the language learner, is one of these problems.

This problem is especially acute while teaching languages with complex grammatical systems. It can be said that Georgian language is one of the complex structures, agglutinative type of language, which differs from other languages not only in phonemic structure, specific sounds (so-called Caucasian sharp

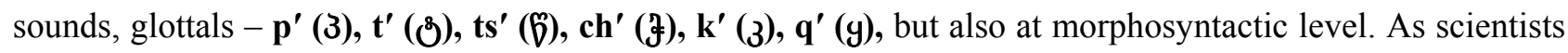
point out, one of the main determinants of complexity and, at the same time, diversity is the polypersonalism of the Georgian verb. I would add to this the abundance and functional diversity of preverbs.

\section{OVERVIEW OF THE ISSUE}

There is a difference of opinions among specialists on the issue of teaching grammar. Some of them completely exclude the teaching of grammar in the process of language learning, while others believe that mastering a language without teaching grammar issues and rules is impossible. If we look through the existing methodological literature and textbooks about teaching Georgian language, we will see that most of the specialists (R. Zekalashvili, M. Odzeli, K. Gabunia, R. Kurdadze, N. Shavtvaladze, N. Sharashenidze, K. Gochitashvili, Tch. Kiria, N. Melikidze...) prefer communicative grammar, delivering grammar issues in the way and at the dose that is necessary to achieve successful communication. The program of teaching Georgian as a foreign language developed by the Ministry of Education and Science of Georgia (author and supervisor of the program M. Odzeli) and the "slope" (from A1 to B2 (+) level) for non-Georgian language learners within the framework of this program is built on this principle. It includes methodological or teaching literature, a series of Georgian language textbooks, in particular, textbooks for language learners, teacher's book, teaching methods, Georgian grammar, dictionary, exercises, etc. (http://www.geofl.ge) 
M. Inasaridze discusses the problems of teaching grammar interestingly in the article "Methodological guidelines for teachers of Georgian as a second language" (2013, http://mastsavlebeli.ge/?p=3707). He chooses the "golden mean" and notes that the goal of non-Georgian language teachers should be "to teach students specific speech acts and operations, linguistic paradigms while teaching grammar, so that they can use this linguistic data knowledge in this or that speech situation. One such way of teaching grammar is through communication" (ibid). Because there are different points of view in the communicative approach (some prefer a thorough knowledge of grammar and some a fluency), from two approaches of teaching grammar, the author gives essential importance to language learners' understanding of the idea that grammatical forms are necessary to solve communicative tasks.

In our opinion, it is necessary to understand and "reconcile" both points of view of the communication approach, taking into account the stages and duration of language teaching. As far as grammar reflects the structure of a language, it is clear that complete mastery of language is impossible without knowledge of the structure of the language to be studied. According to this principle is made R. Saginadze and M. Kikvadze's joint textbook "Gürcüce" (Modül-1, 2) (Georgian language-1, 2). It is intended for students of schools in the Republic of Turkey who will choose Georgian language to study (for several years now, Georgian language has been included as an elective subject in Turkish schools). These two textbooks have been approved by the Turkish Ministry of Education and are available on the Internet (We would like to thank Harun Çimke, Assistant Professor at Recep Tayyip Erdoğan State University for the assistance in the process of working on the book and publishing it).

In this article we will try to show how you can go from easy to difficult at different stages of language learning.

\section{RESEARCH METHODS}

The research in the article is based on the methodology, methods of analysis and comparison in the Georgian or foreign scientific literature. In this aspect is interesting $T$. Kighuradze and E. Kutateladze's work "Methodology of teaching Georgian as a foreign language" (ed. R. Zekalashvili), created within the program of teaching Georgian as a foreign language. The practical assignments given in the book are built on a survey method. The authors focus on teaching and learning grammar issues. For example, assignment 1.1 asks the following questions: "Remember your foreign language lesson. A. What do you remember from the textbook: texts, grammar rules, pictures, exercises or more? B. What was the focus of the lesson (select the correct option for you $\sqrt{ }$ ): speaking, writing, reading, listening, grammar rules..." Assignment 1.2. "A. Have you ever studied or are you teaching by grammar-translation method?" (Kiguradze T., Kutateladze E., 2013: 4); Task 6 is devoted entirely to understanding the teaching of grammar issues (ibid., p. 29-36). For example, one: "Compare different textbooks according to the progress of grammar teaching (use the content)" (ibid., 6.4, p. 30).

\section{RESULTS AND DISCUSSION}

We believe that in the process of teaching Georgian grammar to non-Georgian speakers, it is necessary to take into account several aspects:

1) Subjective and objective factors. Two things are to be considered from the subjective factors:

A. Category of language learner, which includes the level of language proficiency, general level of education, duration of study, etc.;

B. Motivation to learn a language. As they point out, "Motivation is an important issue. If the learner voluntarily participates in the study of an additional language, this may increase the motivation towards the subject itself “ (Do Coil, Philip Hood, David Marsh, 2015: 12); 
Among the objective factors it is necessary to consider such issues as:

A. Structure, nature and specifics of the language to be studied (target);

B. Peculiarities of the learner's native language.

2) The form of language teaching. Of particular importance in teaching is which language we teach: language teaching "in one language" or with the help of the learner's native language? If we look through the Georgian language textbooks for non-Georgian speakers, we will see that the attitude of specialists on this issue is nonhomogenous: some prefer bilingual (Georgian-English, Georgian-Russian, Georgian-Azerbaijani, Georgian-Armenian...) teaching (L.Geguchadze, N. Shavtvaladze, R. Kurdadze ...), some - "in one language", teaching Georgian only in Georgian.

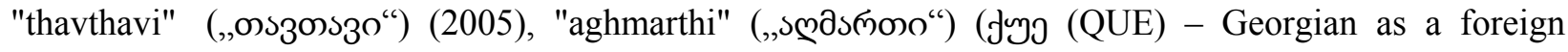
language) developed within the project of the Ministry of Education and Science of Georgia are built on this principle... There are also mixed type textbooks. For example, N. Sharashenidze's book "Midamo-1"

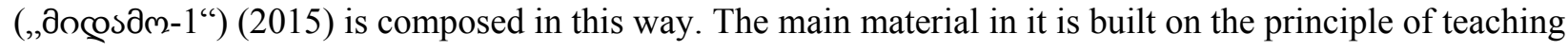
"one language", and the dictionary attached to the book for topics, necessary words and phrases, a short course on Georgian grammar, a mosaic of verbs... is of mixed (translation) nature (Sharashenidze N., 2015: 116-248).

Although we do not exclude completely the possibility of including explanatory translation material in the textbook, in the teaching process we support the principle of teaching only "one language". Thus, we have compiled, for example, the above-mentioned textbooks ("Gürcüce", Modül-1, 2), in which only the dictionary is bilingual (Saginadze, R., Kikvadze, M., 2018).

3) Terms of delivery of grammatical material. Problems to consider in this regard:

A. When, at what stage should grammatical material be provided;

B. What dose of grammatical material should be

supplied;

C. How to provide grammatical material.

Taking into account these aspects, we distinguish the forms of teaching Georgian grammar issues according to the levels of language proficiency:

I. Level of learning reading and writing - So called "Phrasal grammar", i.e. grammar at the level of phrases

II. Level of knowing reading and writing - communicative grammar, elementary grammar

III. In accordance with the increase of the level of language proficiency - increasing the delivery dose of grammar issues.

We also believe that teaching at the initial stage should be aimed at enhancing communication competence, i.e. grammatical material should be provided at the dose necessary for practical communication. This is possible not through verbal but through non-verbal means, which should be reflected in the ready-made communication phrases, exercises, schemes ... 
We will touch on each stage and form of language teaching:

I. Level of learning reading and writing - at this level grammar is almost excluded, everything is only in phrases (listening, writing, reading, speaking), i.e. it is grammar at the level of phrases, which can be called "phrasal grammar". It follows such communication topics as: acquaintance, identity, greeting, farewell, regards, family ...

II. Level of knowing reading and writing - Since the language learner already knows how to read and write in Georgian, we gradually move to the field of communicative grammar. With very simple schemes and exercises we focus on the issues necessary for communication. Take, for example, the topic of "dating".

df3os (mqvia) - My name is is introduced with the help of already familiar verb 3 sल (var) - I am

\section{Scheme 1.}

What is your name?

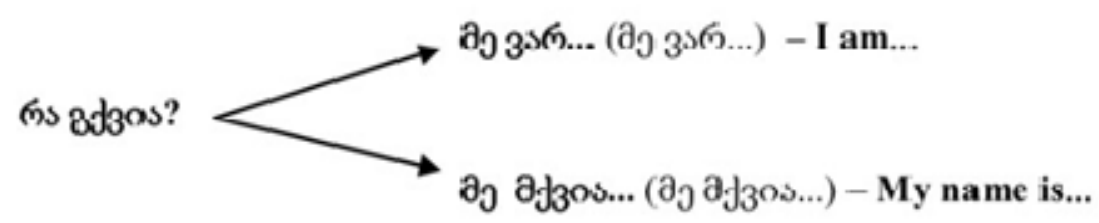

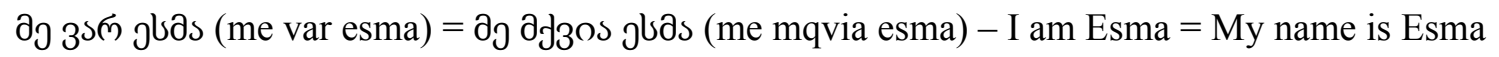

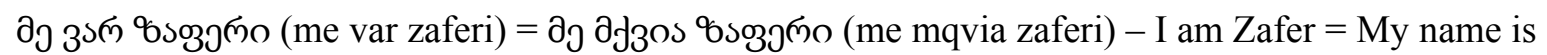
Zafer.

When it comes to identifying, most language learners use their own name as a base according to the grammatical rules of their native language. Writes or says, for example, like this: My name is soðjб (aishenur) - Aishenur, the father's name is bm6j( (soner) - Sonner. In this case we personally pay attention to our own name and point to the sign with the -o sign: My name is soðjбøym-o (aishenur-i) Aishenur-i, the father's name is bm6j(n-o (soner-i) - Sonner-i. After entering the possessive pronoun we

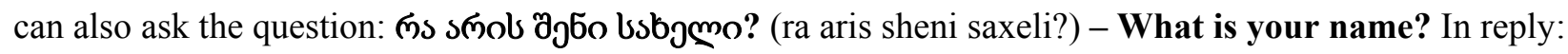

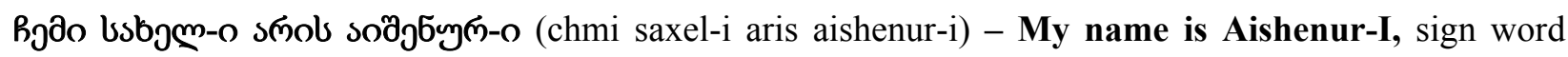
noun -i (-o) indicates that the language learner should attach his / her own name -i (-o); Problems also

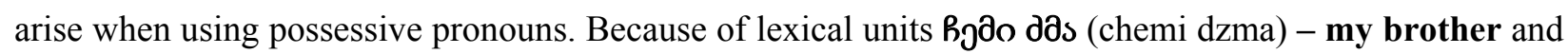

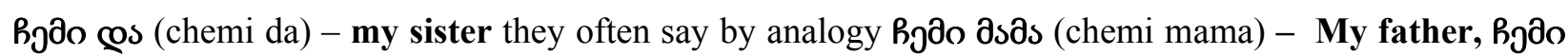

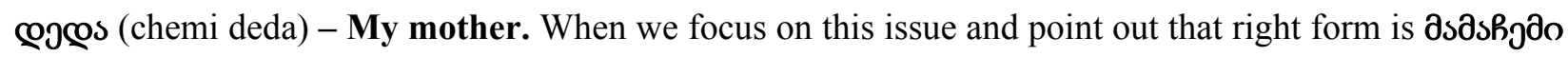

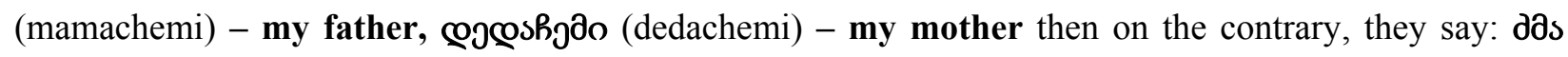

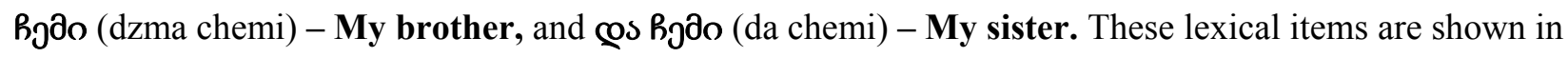
different colors (incorrect form in red) on the principle of true-false (plus-minus) by means of a table: 


\section{Table 1.}

\begin{tabular}{|c|c|}
\hline lsfmrnos + & 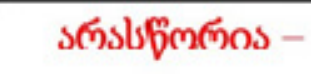 \\
\hline 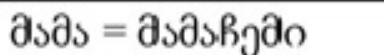 & 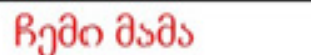 \\
\hline 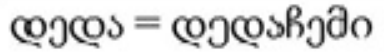 & Rјдо œэœ.s \\
\hline Proa das & das ควao \\
\hline Rjao es & cos Rృдо \\
\hline
\end{tabular}

After overloading the topics with material we can introduce elementary grammar issues with scheme only. For example: we start with a noun, we distinguish who and what group, animate and inanimate nouns, nominative case forms, personal, possessive and demonstrative pronouns, a couple of adjectives, 3 sm (var) I am and dfzos (mqvia) - my name is. The present tense forms of verbs in the singular and plural. We pay language learner's attention to the dative constructions of verbs $3 \mathrm{j} 3 \mathrm{~s}$ (hqvia) - His name is, s s $3 \mathrm{l}$ (aqvs) -

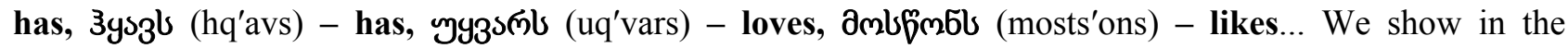
scheme:

\section{Scheme 2.}

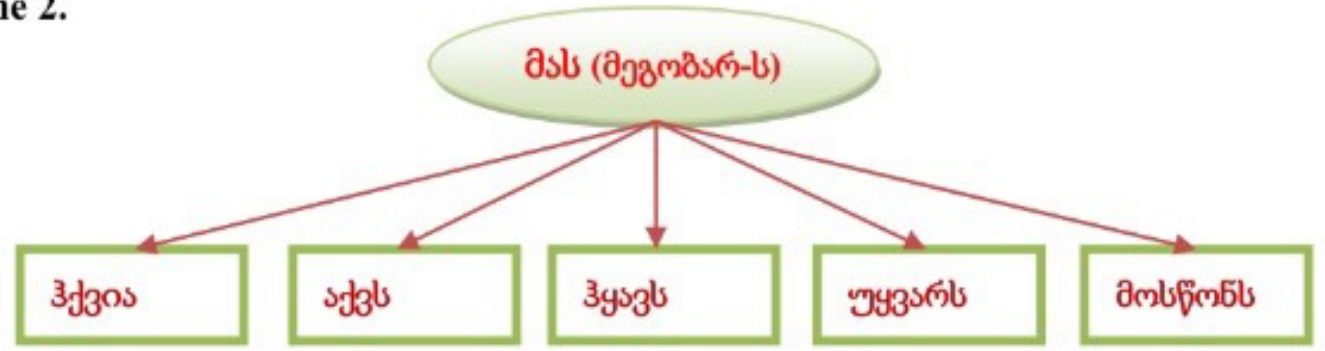

This is the grammar issues of the first topic of the next step, for example, "Introduction". Within the framework of such plan, the relevant grammar issues are included in all the topics, for example, cases, numerical nouns, verb forms (only in the present) are added ... all this only with schemes and not with theoretical material.

Table 2.

\begin{tabular}{|c|c|c|c|c|c|}
\hline \multicolumn{2}{|c|}{ ة } & \multicolumn{2}{|c|}{ 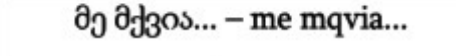 } & \multicolumn{2}{|c|}{ 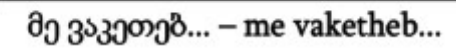 } \\
\hline วэ $3^{\text {ग๓ }}$ & в $_{39^{6}} 3^{\text {smom }}$ & дэ әђзоs & $R_{3} j^{5} 33 \mathrm{~J}^{2}$ & วง $3^{\lrcorner} 39^{\circ}$ & в \\
\hline כjб bsল & ๓л3วб bsต๓ & 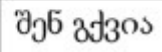 & 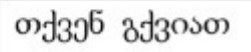 & 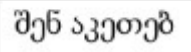 & 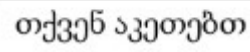 \\
\hline ob smols & obo6o smо & 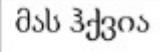 & 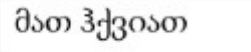 & 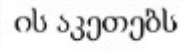 & 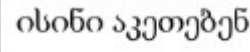 \\
\hline
\end{tabular}

At this point we focus on verb constructions. For example, the verb expressing obligation and will (y5es (unda) - must, dobcos (minda) - I want) and other constructions, which we show through the Scheme: 


\section{Scheme 3.}

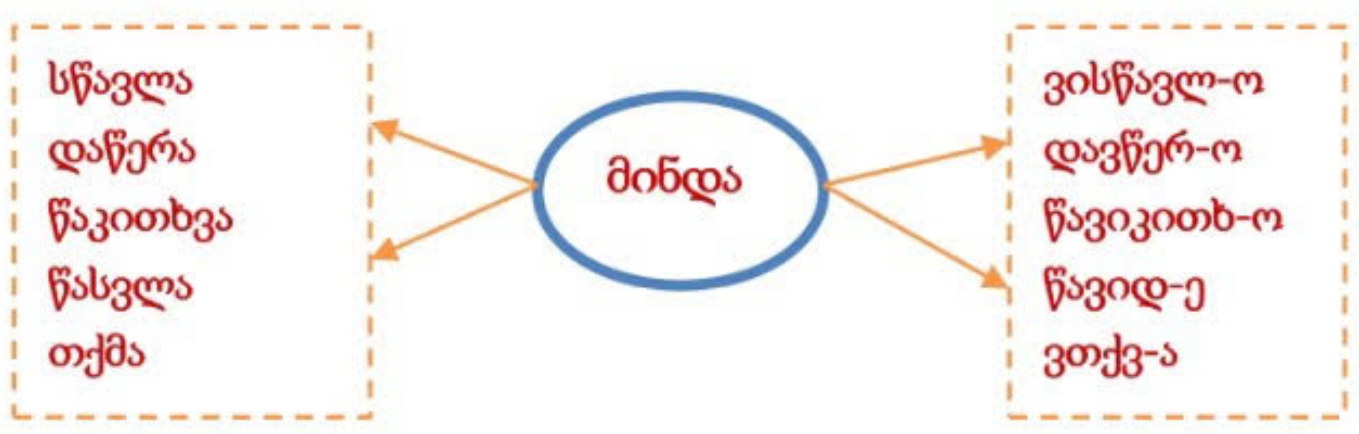

Saginadze R., Kikvadze M., 2018

III. In accordance with the increase of the level of language proficiency - increasing the delivery dose of grammar issues. From this point, we focus on teaching verb forms. We introduce the forms of all three tenses of the verb (present, future, past) (18 in total). We give exercises for writing a verb in the table of different time forms.

Table 3.

\begin{tabular}{|c|c|c|c|c|c|}
\hline \multicolumn{2}{|c|}{ sbessбৎу } & \multicolumn{2}{|c|}{ дмдsзsмmo - future } & \multicolumn{2}{|c|}{ formbugno-past } \\
\hline วэ $363^{\text {n }}$ & 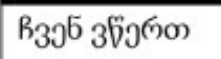 & วэ & 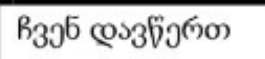 & 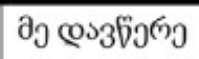 & 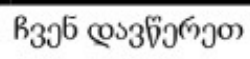 \\
\hline 20 & 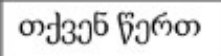 & $z^{6} \cos 6 \jmath^{5}$ & 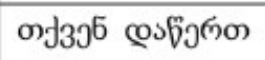 & 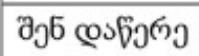 & ๓ $33^{5} \cos 6 \jmath^{\text {m }}$ \\
\hline 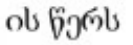 & 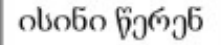 & ob cosfor & 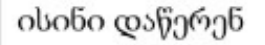 & as6 cosfogns & 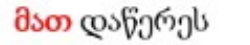 \\
\hline
\end{tabular}

We will separate the preverb forms separately. With a schematic representation of simple and complex verbs we show the language learner the functions of the verb and also how it is possible to study in a very short time verbs with the same root but with different meanings.

\section{Scheme 4.}

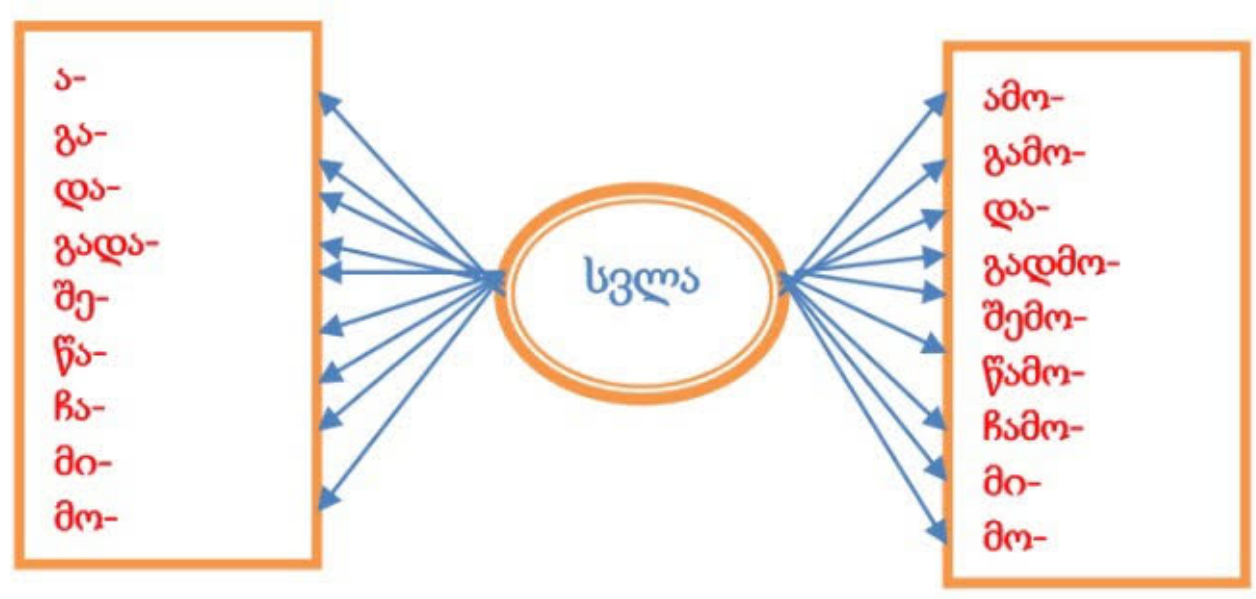

Saginadze R., Kikvadze M., 2018 


\title{
CONCLUSION
}

With the help of a small amount of material, we tried to show some aspects of teaching Georgian grammar to non-Georgian speakers, namely, how to introduce grammatical material in Georgian language teaching step by step, according to language proficiency levels (and not all at once) with schemes, tables, exercises and not with theoretical material and rules, in excessive doses.

\section{REFERENCES}

Inasaridze, M. (2013). methodikuri mithithebebi qarthulis, rogorc meore enis, masts'avlebelthathvis ("Methodological guidelines for teachers of Georgian as a second language"): http://mastsavlebeli.ge/?p=3707

Do Coil, Philip Hood, David Marsh (2015). enisa da sagnobrivi shinaarsis integrirebuli sts'avleba ("Content and Language Integrated Learning") (transl. G.Gabunia, ed. K. Gochitashvili), Tbilisi: https://www.cciir.ge/images/pdf/CLIL.pdf

Kighuradze, T., Kutateladze, E. (2013). qarthulis, rogorc ucxo enis, sts'avlebis methodika ("Methodology of teaching Georgian as a foreign language" (ed. R. Zekalashvili), Tbilisi (4; 29-36): https://www.sjuni.edu.ge/ebiblioteka/images/books/qartuli\%20enis\%20swavlebis\%20metodika\%20 pra qt.pdf

Saginadze, R., Kikvadze, M., "Gürcüce" (Modül-2) (Georgian language-2), (2018):

https://www.mebders.com/dosya/8390-8sinif-gurcuce-modul-2-ders-kitabi-pdfindir?fbclid=IwAR0M0 4INR2UACeoutOxYokynoAwONQTvqkgNIqy4GtodaX7G3iD22E9maY

Sharashenidze, N. (2015). "Midamo-1", Tbilisi (116-248).

http://www.geofl.ge

For citation:

Saginadze, R. (2020) Georgian language grammar teaching aspects for non-georgian speakers // International ScientificPedagogical Organization of Philologists “WEST-EAST" (ISPOP). Scientific Journal "WEST-EAST". Vol. 3, N1 (October, 2020). pp. 62-69. https://doi.org/10.33739/2587-5434-2020-3-62-69

\section{Для цитирования:}

Сагинадзе, P. (2020) Аспекты преподавания грамматики грузинского языка для негрузиноговорящих // International Scientific-Pedagogical Organization of Philologists "WEST-EAST" (ISPOP). Scientific Journal "WESTEAST”. Vol.3, N1 (October, 2020). c. 62-69. https://doi.org/10.33739/2587-5434-2020-3-62-69

Information about the author:

Saginadze Rusudan - Doctor of Philology, Professor, Head of the Department " Georgian language", Akaki Tseretely State University, Kutaisi, Georgia

e-mail: r_saginadze@yahoo.com

\section{Сведения об авторе:}

Сагинадзе Русудан - доктор филологии, профессор, руководитель направления «Грузинский язык», государственный университет имени Акакия Церетели, Кутаиси, Грузия e-mail: r saginadze@yahoo.com

Manuscript received: 15/08/2020

Accepted for publication: 14/09/2020

Рукопись получена: 15/08/2020

Принята к печати: 14/09/2020

\author{
International Scientific-Pedagogical Organization of Philologists "West-East" - ISPOP \\ SCIENTIFIC JOURNAL "WEST-EAST" \\ ISSN (print) - 2587-5434 ISSN (online) - 2587-5523
}

